\title{
The Aid-India Consortium, the World Bank, and the International Order of Asia, 1958-1968*
}

\author{
Shigeru AKITA \\ Osaka University \\ Osaka, Japan \\ akita@let.osaka-u.ac.jp
}

\begin{abstract}
The Aid-India Consortium was organized in 1958 as an international scheme to support the economic development of India, and led by the World Bank. This article reconsiders the economic diplomacy of the Indian Government in the 1950 s and 1960s, by paying attention to the interactions between the Indian authorities and the donor countries and institutions, in the context of the Cold War regime, decolonization and economic aid to the newly independent countries.

First, it deals with the development of the Aid-India Consortium by considering debates at its annual meetings and the skillful negotiations of the Indian Government and financial authorities. It focuses especially on the leading role of an Indian diplomat and financial expert, B. K. Nehru. The article then tries to reveal an Indian initiative in solving the 'food crises' of 1965-67 through intimate collaboration with the US government and the World Bank, using the framework of the Aid-India Consortium. These attempts lead to a reconsideration of the economic order of Asia in the 1950 and 1960 .
\end{abstract}

* The earlier version of this article was presented at the Imperial and World History Seminar, Institute of Historical Research, University of London on 24th March 2014. The author highly appreciates kind comments and suggestions from Prof. Richard Drayton (seminar organizer) and participants, and kind arrangements by the archivists at the Bank of England Archives, the Reserve Bank of India Archives and the World Bank Archives. This research was financially supported by Japan Society for the Promotion of Sciences (JSPS) grants. 


\section{Key words}

Aid-India Consortium, economic aid, World Bank (International Bankfor Reconstruction and Development), B. K. Nehru

This article aims to reconsider the economic diplomacy of the Indian Government in the late 1950 os and 1960s (1958-68), in connection between international economic-aid programmes and the formation of the international order of Asia, by focusing on the Aid-India Consortium. The Indian government started its Five-Year Development Plan in 1951, and full-scale development planning was introduced in the Second Five-Year Plan (1956-61), under the strong leadership of Jawaharlal Nehru and P. C. Mahalanobis. At the initial stage of the Second Five-Year Plan, foreign economic aid to India played a minor role as financial resources for economic development.

However, from 1958, under the 'crisis' of foreign exchange and balance of payments, a new scheme of multinational foreign-aid was formed under the leadership of the World Bank (International Bank for Reconstruction and Development: IBRD). This Aid-India Consortium reflected the mutual interaction of the Cold-War regime, decolonization in Asia, and the remaining influence of the UK and the sterling area in the 1950 ond 1960 . The Indian government under the Nehru administration played a key-role in the negotiations of the Consortium. The leading Indian figure in the formation of the Aid-India Consortium was B. K. Nehru, a nephew of Jawaharlal Nehru and the financial expert of the Indian government.

By using the documents of several archives, including the Bank of England, the Reserve Bank of India, the World Bank Archives and the National Archives of India, and especially the B. K. Nehru Papers at the Nehru Memorial Museum and Library (Teen Murti House), this article reconsiders a crucial importance of multilateral economic aid for India, and presents the dynamic role of Indian economic nationalism through the activities of Indian elites in the international banking and financial world. 
1. THE NEW INTERNATIONAL ORDER OF ASIA AND INDIA IN THE 1950S AND $1960 \mathrm{~S}$

First, we consider the newly emerging international order of Asia in the 1950 and 1960 s and the position of India within it. Based on traditional interpretations of the 1950 os and 1960s in Asia (South Asia and Southeast Asia), political decolonization and the formation of the Cold-War regime have been interpreted as two major trends in international relations. India played important roles in the acceleration of decolonization. The Indian Prime Minister, Jawaharlal Nehru, took a strong initiative in forming an independent international political order of Asia-Africa, at the Bandung Conference in Indonesia in 1955 .

As for economic aspects of the order in Asia, many works have been done in the new academic field of developmental economics. India has attracted strong and keen attentions in this new academic field, owing to the great achievement of the Nehru-Mahalanobis model of the developmental strategy for constructing the national economy. ${ }^{1}$ But the basic framework of analysis is that of national economy or newly-emerging nation state in Asia and Africa after political decolonization. By mainly focusing on either political and diplomatic relations, or on establishing a national economy, previous studies on international order of Asia in the 1950s seemed to neglect external linkages or connections of the economic order in Asia in the 1950 .

However, some works by economic historians are worth mentioning. The Government of India took an active role in the formation of international-aid plans in South and Southeast Asia in the late 1940 and early 1950 . A typical example was the formation of the

${ }^{1}$ Terence Byres, ed., The Indian Economy: Major Debates since Independence (Delhi: Oxford University Press, 1998); Esho Hideki, Kaihatsu-Keizaigaku to Indo (Developmental Economics and India) (Tokyo: Nihonhyoron-sha, 2002). 
Commonwealth-based economic aid programme, the Colombo Plan, which was discussed at the Commonwealth Foreign Ministers meeting in Colombo (January 1950) and at the Consultative Committees in Sydney (May 1950), London (September 1950) and finalized in Colombo (February 1951). ${ }^{2}$ India could utilize its accumulated sterling balances as a financial resource for the Colombo Plan by the mid-1950s. The author tried to reveal a kind of continuity of the economic order in the 1930 and 1950 os in East Asia, by focusing on the revival of 'intra-Asian trade' in the 1950s, through a joint-research project. ${ }^{3}$

Concerning the economic policies of the Indian government, B. R. Tomlinson's second edition of The Economy of Modern India presents us a comprehensive observation, ${ }^{4}$ but it does not pay enough attention to the role of external economic aid to India. However, as for the financial and fiscal policies of the Indian government, the history of the Reserve Bank of India [RBI], edited by G. Balachandran, is insightful and useful. He describes the chronological development of financial and banking policies, managed by the RBI, especially crisis management and devaluation in the 1960 s. $^{5}$ A work by Tirthankar Roy is also helpful in obtaining an overview about the relationship between foreign aid and Indian economic growth. ${ }^{6}$

${ }^{2}$ B. R. Tomlinson, “'The Weapons of the Weakened': British Power, Sterling Balances and the Origins of the Colombo Plan," in The Transformation of the International Order of Asia, ed. Shigeru Akita, Gerold Krozewski, and Shoichi Watanabe (London and New York: Routledge, forthcoming); Shoichi Watanabe, ed., Colombo Plan: Sengo Ajia Kokusaichitsujyo no Keisei (The Colombo Plan and the International Order in Asia after World War II) (Tokyo: Housei University Press, 2014).

${ }^{3}$ Shigeru Akita and Nicholas J. White, eds., The International Order of Asia in the 1930s and 1950s (Surry and Burlington: Ashgate, 2010).

${ }^{4}$ B. R. Tomlinson, The Economy of Modern India: From 1860 to the Twenty-First Century, 2nd ed. (Cambridge: Cambridge University Press, 2013), chapter 4. 1998).

${ }^{5}$ G. Balachandran, The Reserve Bank of India 1951-1967 (Delhi: Oxford University Press,

6 Tirthankar Roy, "Foreign Aid and Economic Growth in India: The Changing Relationship," in The Aid Rush: Aid Regimes in Northern Europe during the Cold War, 2 vols (Oslo, Norway: Oslo Academic Press, 2008). 


\section{ECONOMIC ASSISTANCE TO INDIA AND THE AID-INDIA CONSORTIUM}

\subsection{Historical Backgrounds of the Aid-India Consortium}

First, we consider the historical background for the start of the Aid-India Consortium in August $1958 .^{7}$ For the newly independent Asian countries, economic development was crucial for the stability of the new governments and for solving problems of poverty. The Indian government started its Five-Year Plan in 1951 and it was quite successful. Following the First Five-Year Plan, they continually pursued the Second Five-Year Plan (April 1956-March 1961) and the Third Five-Year Plan (April 1961-March 1966). The turning point of these successive economic plans for development came in 1958, when India faced a 'crisis' of foreign exchange and balance of payments. In the previous year of 1957, Indian sterling balances in London were almost exhausted, except for working balances, due to heavy imports of capital goods for the acceleration of the Second Five-Year Plan.

Under this financial 'crisis' situation, the Indian administration, led by Jawaharlal Nehru, had to solve financial difficulties, by getting external assistance as well as by its own efforts to reduce imports. India has continually received economic bilateral aid from several countries since its independence ${ }^{8}$ and became the largest recipient country of development aid from the World Bank. For the World Bank, as the second largest lending institution next to the US, an emergency rescue operation for India was necessary. In this sense, "India has influenced the [World] Bank as much as the Bank has influenced India." 9 The new feature of the Aid-India Consortium was

${ }^{7}$ As for a brief history and mechanism of Aid-India Consortium, see Working Paper: India Consortium (80480) (World Bank, July 1968), http:documents.worldbank.org/curated/en/1968/07 /18129542.consortium.

8 India had received the first loan from the World Bank on August 18, 1949, in order to develop the railways. It had been a part of bilateral foreign economic aid to India.

9 Edward S. Mason and Robert E. Asher, The World Bank since Bretton Woods (Washing- 
the style of multilateral aid coordination in the form of a Consortium, led by the IBRD (later the World Bank). This new kind of multilateral style aid was easily accepted by Nehru Administration because of the leadership of the World Bank, a newly-established international organization. Jawaharlal Nehru's independent diplomacy under the Cold-War situation was suitable to multilateralism.

\subsection{Economic Assistance to India in the 1950 and 1960 S}

In this section, we confirm the records and trends of economic assistance to India in the 1950 os and 1960s (See Graphs). Based on the description of B. K. Nehru and corrected by the statistics in the Economic Survey in India, ${ }^{10}$ we may have the following statistics of economic aid to India.

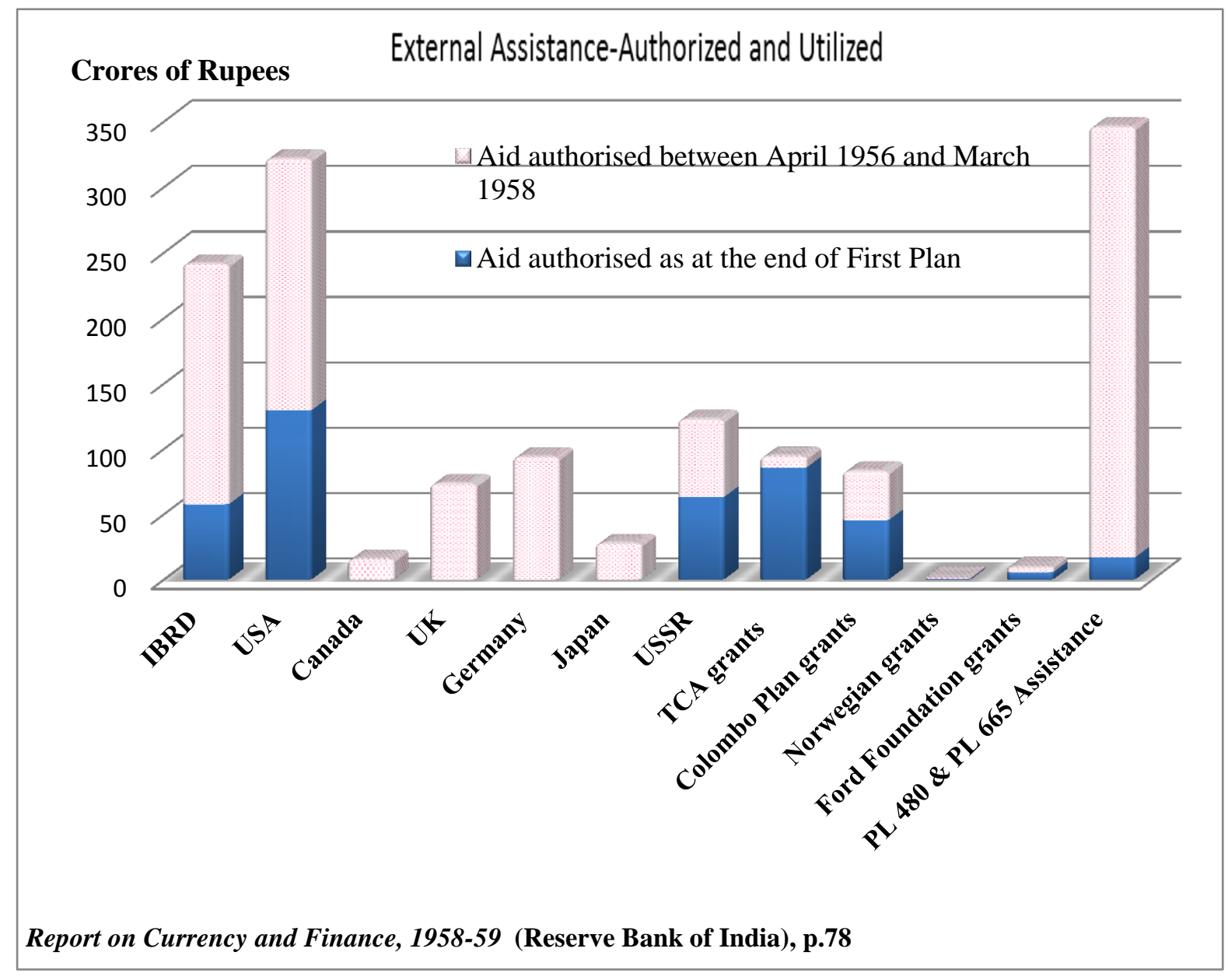

ton DC: The Brookings Institution, 1973), 675.

${ }^{10}$ Government of India, Economic Survey 1965-66; 1966-67 (New Delhi: Government of India Press, 1966, 1967)_External Assistance. 
During the First Five-Year Plan (1951-56), disbursements of foreign aid amounted to $\$ 424$ million (Rs. 202 crores) of which $\$ 190$ million (Rs. 90 crores) represented the US wheat loan. Excluding this rather special loan, foreign aid accounted for only 3.3 percent of total investment during the First Plan. In addition, foreign exchange reserves [sterling balances] were drawn upon to the extent of $\$ 267$ million (Rs. 127 crores). ${ }^{11}$

India's reliance on foreign aid was only marginal during the First Plan.

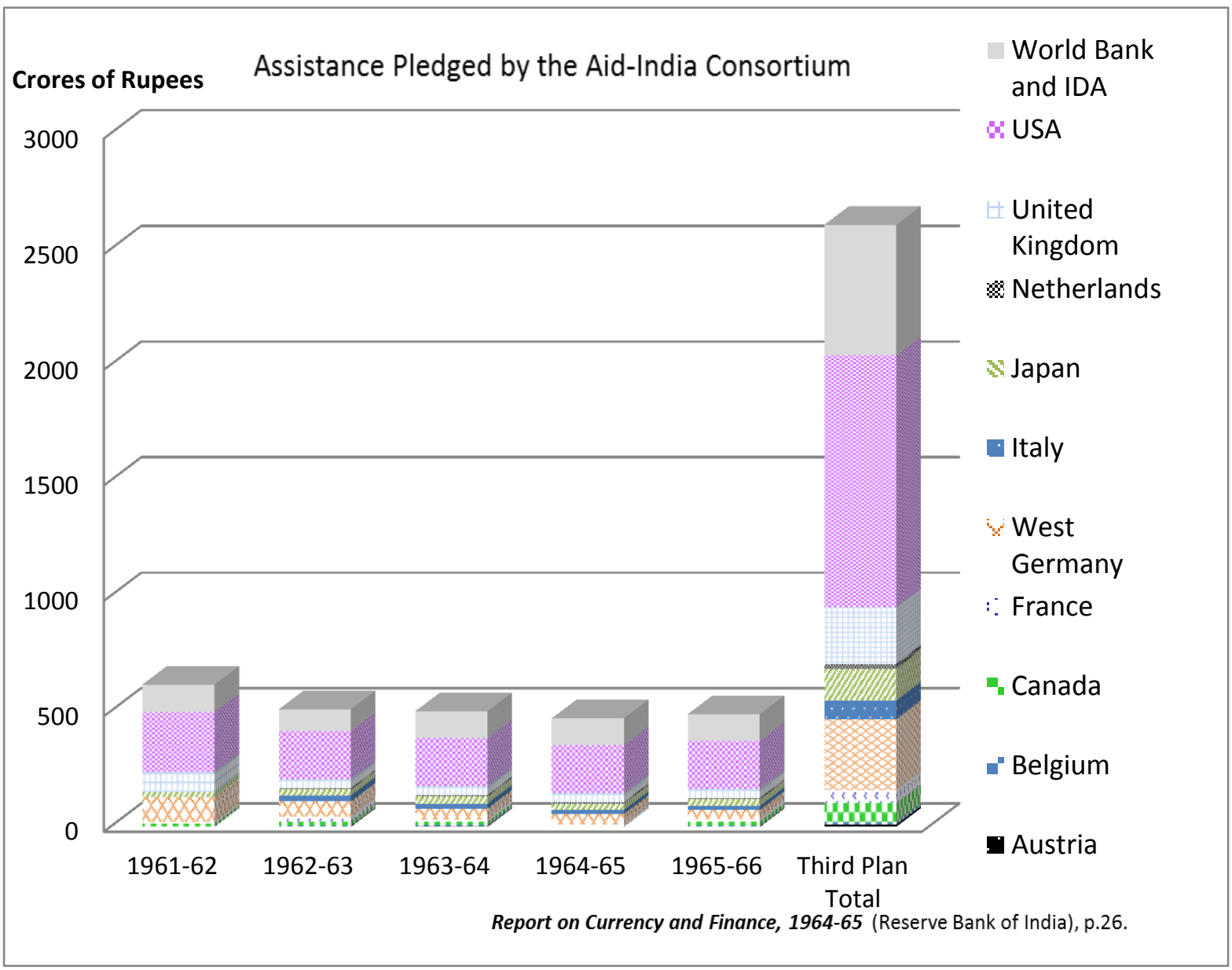

As against the original estimate of a balance of payments gap of \$2.31 billion (Rs. 1100 crores) and total investment of $\$ 13.02$ billion (Rs. 6200 crores) the actual gap turned out to be as large as \$4 billion (Rs. 1912 crores) and investment roughly $\$ 14.3$ billion (Rs. 6830 crores). As much as $\$ 3$ billion (Rs. 1430 crores) of the gap was covered by aid and the rest by foreign exchange reserves and net drawing on the International Mone-

11 B. K. Nehru, "Foreign Aid: Retrospect and Prospects," The Shastri Memorial Lectures organized by the Institute of Public Enterprise, 12-13 January 1968, New Delhi, B. K. Nehru Papers, III-A Speeches/Writings by Him, s no.9 [Nehru Memorial Museum \& Library]. 
tary Fund (IMF). There cannot be a better testimony to the contribution of foreign aid to our Second Plan than a recitation of these simple facts.

But the hey-day of foreign aid in India was reached during the formative period of the Third Five-Year Plan (1961-66) . . . During the Third Plan period, as much as $\$ 5.2$ billion (Rs. 2488 crores) worth of new aid was committed and $\$ 4.2$ billion (Rs. 2016 crores) worth actually disbursed . . . Taken together and after deducting debt service charges, net foreign aid actually utilized during the Third Plan amounted to roughly $\$ 4.83$ billion (Rs. 2300 crores) or some $21 \%$ of net investment in the economy. ${ }^{12}$

From these observations of B. K. Nehru himself, we may recognize that the importance of foreign economic aid was progressively increased along with the development of successive Five-Year Plans in the late 1950 and the early 1960 .

A report by the Bank of England of August 1959 shows the amount and purpose of international capital assistance allocated to underdeveloped countries at the time (Table). The US was the biggest donor country, while the UK occupied the second position in overseas capital aid. The Bank pointed out that "[t]he total of 'assistance' to the underdeveloped countries is thus of the order of \$4 billion per annum at the present time. Over $\$ 800$ million of the ICA (International Cooperation Administration) assistance took the form of defence support aid-of which nearly three-quarters went to Far Eastern countries-particularly Korea and Vietnam, and is perhaps closer to being political assistance than development aid. But even if the whole of the defence support aid is subtracted, the total appears to have exceeded \$3 billion." UK figures of $£ 150$ million for the use of sterling balances was intended as a broad indication of how much the underdeveloped countries may have drawn on their balances for 'development' as opposed to normal reserve fluctuations. ${ }^{13}$

According to this Bank report, the UK allocated aid of $£ 238$ million (\$666 million), roughly 16 per cent of the total, including the use

${ }^{13}$ Note on "Development Assistance," August 21, 1959, by the Bank of England, Bank of England Archives [BoE] OV 171/1 (706). 
of sterling balances. The bulk of the government assistance by the US and the UK was for military purposes. Military assistance was closely linked to the emerging Cold War regime in the global context.

Table 1. Development Assistance, 1958-59

(£mns.) (USD\$mns.)

\begin{tabular}{llc}
\hline UK & & \\
\hline & & 35 \\
(a) Inter-governmental loans & 33 \\
(b) Grants & 15 \\
(c) London Market loans & 5 \\
(d) Colonial Development Cor. & 150 \\
(e) Use of sterling balances & (say) & $\underline{£ 238}=\underline{\$ 666}$ \\
\hline
\end{tabular}

USA

(a) International Cooperation Administration (ICA)

(i) Technical assistance

(ii) Development assistance

(mainly Development loan Fund)

(iii) Defense support

(iv) Other assistance

(b) Export-Import Bank

(Annual rate, say)

(c) P.L.480

(Annual rate, say)

900

$\underline{\text { Subtotal }}$

International Organization

(a) I.B.R.D 426

(b) International Finance Corporation (IFC)

Subtotal

\begin{tabular}{ccr}
\hline Others & Germany and Japan & (say perhaps) \\
Subtotal & & 100 \\
\hline Grand Total & $\$ 100$ \\
\hline
\end{tabular}

Source: “Development Assistance,” August 21, 1959, By Bank of England OV171/1(706) 
2.3 The Meetings of the Aid-India Consortium: Donor Sides' Arguments

In this section, we analyze the core arguments of donor countries of the Aid-India Consortium, in order to reveal the development and transformation of the Consortium itself.

The Consortium started as a short-term and emergency programme at the IBRD meeting in August 1958. The first meeting was held on the initiative of the President of the IBRD, Eugene Black, and five donating countries to India, the UK, the USA, West Germany, Canada and Japan participated (the IMF was an observer) in order to prevent India from lapsing into financial difficulty as the largest borrowing country in the Third World. From the Indian side, B. K. Neh$\mathrm{ru}$, the Indian Director of the IBRD \& the Financial Adviser at the US Embassy, attended the meeting in Washington D. C. in August 1958, ${ }^{14}$ and he was to continually play a leading role in the negotiations with the Aid-India Consortium. Before leaving for his new post in Washington D. C. in August 1958, B. K. Nehru regularly visited London, Paris and Washington D. C. once a year for private and public consultations and talks with Anglo-American and European specialists in international finance. ${ }^{15}$

At the first meeting, the British expected the influence of the IBRD to formulate a new framework of "international cooperation," and showed anxiety for the limitation of British financial resources and its impact on the balance of payments of the UK. They took an ambivalent attitude to the Second Indian Five-Year Plan, but were rather optimistic about the longer perspective up to the end of the Plan, March 1961. In conclusion, the British government agreed to offer the largest share ( $\$ 108$ million=38.5 million pounds; $30.8 \%){ }^{16}$

14 B. K. Nehru, Nice Guys Finish Second: Memoirs (New Delhi: Viking, 1997).

15 "Records of Deputation of B. K. Nehru outside India (1954-64)," B. K. Nehru Papers, III-B Diaries/Notebooks, No.8 [Nehru Memorial Museum \& Library].

${ }^{16}$ Bank of England Archives, Country Files: India OV56/57 (1958), "India: Washington Discussions, 25-28 August," 29/08/1958 [BoE]. 
This decision was closely related to the central position of the sterling area and Indian sterling balances. In March 1959, the second meeting of the Consortium was held in Washington D. C. The UK delegation worried about the rapid decrease in Indian sterling balances (£223 $\mathrm{m}$ in Dec. 1957; £138 m in Sep. 1958; £158.6 m in Feb. 1959). The Bank of England pointed out the limitation of donor countries and mentioned that "UK must be prepared for further drawings on existing balances, largely for development, and has the responsibility of maintaining sterling as an international \& reserve currency."17

After the second meeting, the UK paid attention to the "political aspects of Aid to India." A Bank official clearly pointed out that "our attitude to the Indian Third Five-Year Plan should be decided on merits and should not be influenced by any attempt to out-bid the Russians." ${ }^{\text {"18 }}$ One British paper also referred to the merits of competition in aid for India: "From India's point of view, Soviet Bloc participation in her economic development has a number of advantages ... politically, (it) has allowed India to give a practical application of her policy of neutralism by freeing her from complete dependence on Western sources of capital and technical advice."19

The third meeting was held in Washington D. C. in March 1960 to make a review of its achievements. And at the fourth meeting in Paris in September 1960, B. K. Nehru urged foreign economic assistance of around £1500m.- £1750m. For the Third Plan, almost double the sum of the Second Plan. He also requested more generous terms of loan (longer terms and untied aid). The meeting basically approved an outline of the Third Plan. The Consortium itself received a strong support from the new US Kennedy Administration, as well as

17 Ibid., OV56/60 (1959), "Bank Paper; Development Finance," 29/07/1959 [BoE].

18 Ibid., OV56/60 (1959), "Note: Indian Third Five Year Plan," from Rumbold (BoE) to Denis Rickett (Treasury), 12/06/1959 [BoE].

19 Ibid., OV56/60 (1959), "India's Economic Relations with the Sino-Soviet Bloc," 15/06/1959 [BoE]. 
through the affiliation of new five donor countries (France in April 1961; Austria, the Netherlands, Belgium and Italy in May 1962).

However, from the middle of 1962, another 'crisis' in the Indian balance of payments occurred, for several reasons. The Indian finance minister, Morarji Desai, attributed it to the gap between promised aid and actual delivery, and to "inadequate provision for current imports." At the sixth meeting in Washington D.C. in May and July 1962, the British defended India's position as a member of the sterling area: "it would be a bad thing for the strength of sterling for an important country in the Sterling Area to get into serious balance of payments difficulties." The British delegation proposed a collective approach to the 'crisis' in the Indian balance of payments. ${ }^{20}$

In October 1962, the Indo-China border dispute broke out and India was completely defeated. The Indian government urgently requested the US and the UK for military aid and support against China. The Commonwealth Relations Office (CRO) of the UK proposed prompt and generous aid (military and economic) to India, but the Treasury and the Bank of England took more cautious attitudes to the Indian request and strongly insisted on a clear distinction between economic and military aid, which were not compatible with the multilateral aid coordination of the Consortium. ${ }^{21}$ At the seventh preparatory meeting in Washington D. C. in April-May 1963, the British emphasized the burden of military aid to India and its pressure on British finance and balance of payments.

The eighth meeting was interrupted by differences of opinion among donor countries in June in Paris and in Washington D. C. in August 1963, due to the shortage in promised amounts of aid. In addition, the UK emphasized the importance of non-project aid, and the US and Canada supported the British opinion, but failed to de-

${ }^{20}$ Ibid., OV56/68, "Dispatch: Aid to India," 25/05/1962; "Treasury Note: Aid to INDIA," 26/06/1962 [BoE].

${ }^{21}$ Ibid., OV56/69, "Note of a Meeting to Discuss Assistance to India," 02/11/1962; "Indian and Pakistan Consortia: Letter from P. S. Milner Barry (Treasury) to D.B. Pitblado (British Embassy, Washington)," 14/03/1963 [BoE]. 
termine the general trends of the Consortium. Finally, US, Austria, West Germany, Italy, Japan, and the IBRD agreed to increase their offer to reach a target ( $\$ 1,052$ million). About two-fifths of the aid was allocated to non-project assistance. ${ }^{22}$ After the eighth meeting, British government officials sought a reappraisal of the role of the Consortium. The British Treasury recognized the changing structure of Indian industry and the progress of import-substitution: "the process of import-substitution, which in India's case is now change from imports of fully made up capital items to imports of components to supplement indigenous production and raw materials ... import demands will tend to show a faster rate of increase than in the early days of industrialization." They feared a further worsening of balance of payments in India, and complained about the irresponsible attitudes of other donor countries: "We shall be financing with our balance of payments assistance the servicing of the mid-term commercial credits offered by the Japanese and a number of European countries."23

The tenth meeting of the Consortium was held in Washington D. C. in May 1964 and agreed to offer $\$ 1,028$ million (UK only $\$ 84$ million). After this meeting, the Bank of England took a critical stance against the Indian debt service. A Bank official described the Indian financial position as de facto default in the sense that in recent years it had been unable to meet its obligations without the help of a large and increasing amount of general purpose aid from the Consortium, ${ }^{24}$ and insisted on a combined consortium approach led by the IBRD. The Bank even considered the possibility of collaboration with the USSR: "If this could lead to the opening up of perspectives, at the end of which Soviet bloc membership of the international institu-

${ }^{22}$ Ibid., OV56/71, Foreign Office Telegram: No. Eager 198, from Washington to Foreign Office, 07/08/1963 [BoE].

${ }^{23}$ Ibid., OV56/72, "Treasury Note: Indian Memorandum for the 1964 Consortium Meeting," (Lovell to Mackay) 25/02/1964 [BoE].

${ }^{24}$ Ibid., OV56/74, "Bank Memorandum on Indian Debt Service: from P. L. Hogg to Haslam, Parsons," 05/08/1964 [Boe]. 
tions could be thought as a real possibility, I would think that to be one of the most significant steps forward in international economic relations since the war." ${ }^{25}$ The huge accumulation of Indian debt seemed to be a common interest among donor countries, including the USSR, even under the Cold-War regime in the mid-196os.

From these observations of the Consortium meetings, we may identify three features of the Aid-India Consortium. The first is the coordinated character of the Consortium. As B. K. Nehru frankly admitted, "The Consortium began perhaps as a rescue operation. But it soon emerged as a forum for getting our plans endorsed by the donor countries as a first step towards having their foreign exchange requirements underwritten jointly by the members of the group ... It is not perhaps remembered nowadays that the World Bank and the Consortium had endorsed the general framework and priorities of the Third Plan before it commenced and that there was also a declaration of intent on their part to provide on soft terms all the foreign exchange needed for the Plan after making due allowance for our own earnings and assistance from non-Consortium countries as well as private foreign investment." ${ }^{26}$ The Indian government could fully utilize this cordial character for a smooth start of the Third Five-Year Plan.

The second is the growing importance of US aid to India, even within the Consortium. Except for the first meeting, the US had been the largest donor in the Consortium, with additional food aid through PL 480 (The Agricultural Trade Development and Assistance Act) and PL 665. From around 1963, the US government set the target of an equal amount of counter-offer of finance by other members of the Consortium.

${ }^{25}$ Ibid., OV56/74, "Bank Memorandum on Indian Debt Service: from P. L. Hogg to Haslam, Parsons," 05/08/1964; Ibid., "Indian Debt," 26/08/1964; Bank Memorandum to the Deputy Governor on India's Debt," 28/08/1964 [BoE].

${ }^{26}$ B. K. Nehru, "Foreign Aid: Retrospect and Prospects," The Shastri Memorial Lectures organized by the Institute of Public Enterprise, 12-13 January 1968, New Delhi, B. K. Nehru Papers, III-A Speeches/Writings by Him, s No.9 [Nehru Memorial Museum \& Library]. 
The third point is the changing character of the Consortium in the mid-196os from project-oriented aid to more flexible non-project aid programmes in proportion to the increase in the amount of debt repayment. The US and the UK strongly insisted on a greater allocation of money to non-project aid in order to get an assurance of repayment of debt from the Indian government, and to accelerate Indian imports of semi-finished products and parts for industrialization. Such an attitude of the US and the UK was agreeable to the Indian government as well.

\section{SKILLFUL ECONOMIC DIPLOMACY OF INDIA ON FOREIGN AID}

We have already analyzed the policies and attitudes of donor countries to the Aid-India Consortium. The Indian government skillfully negotiated with donor countries of Consortium, bilaterally as well as multilaterally, through the framework of the Consortium. The main Indian negotiators were B. K. Nehru, Morarji Desai (finance minister 1958-64), the officials of the Reserve Bank of India (RBI) and the Ministry of Finance, like J. K. Jha. In this section, we explore Indian attitudes to foreign economic aid, by using documents from Indian Archives.

3.1 The Attitudes of the Reserve Bank of India to Foreign Economic Aid

First, we analyze the attitudes and opinions of senior officials at the Reserve Bank of India (RBI). The RBI is the central bank in India and was in charge of managing and using the financial resources of foreign aid in India, and it was kept under the control of the Ministry of Finance after its nationalization in 1949.

The Executive Director of the RBI frankly admitted the im- 
portance of bilateral aid for the Third Plan in October 1959, and the need for general purpose credit (=non-project aid), due to the shortage and rapid decrease in Indian sterling balances:

The entire foreign exchange costs of any fresh development during the Third Plan will have to be met through foreign assistance ... In the absence of the large cushion of our own reserves and with the procedural delays which have been observed to be associated with utilization of individual lines of credit available for specific projects or purposes, the need for a substantial amount of general purpose credit will be all the greater. In this context, while we must welcome such attempts as are being made to render the international institutional framework more adequate for meeting the needs of under-developed countries, it appears that major reliance will have to continue to be placed on bilateral credits such as we received during the Second Plan period; these will have to be organized, however, on a larger scale. ${ }^{27}$

At the end of the Second Five-Year Plan, the RBI clearly recognized the crucial role of foreign assistance for the stable economic development of India. As a practical managing agency of foreign exchange in India, the RBI was very keen and sensitive to recognize the problems of foreign exchange and the indispensability of foreign assistance:

Including loans granted by the IBRD and net drawings from the IMF, foreign assistance financed 43 percent of the total deficit in 1956-57, 54 percent in 1957-58, 89 percent in $1958-58$ and 94 percent in 1959-60, the proportion of impact on reserves being thus progressively reduced. We have thus sharply increased the use of foreign assistance and progressively reduced the proportionate impact on reserves in meeting the total external payments deficits, while pursuing a severely restrictive import policy ... Balance of payments developments in the first four years of the Second Plan period as well as the prospects for the last year of the Plan underline the crucial role of foreign assistance in maintaining a high and stable pace of economic development ... In such a context development has, for the time being, become very largely a fiction of foreign aid. ${ }^{28}$

${ }^{27}$ F41467, Memorandum to the Central Board: The Foreign Exchange Position by Economic Department, Reserve Bank of India, 17/10/1959, by B. K. Madan, Executive Director [Reserve Bank of India Archives: RBI, Pune].

${ }^{28}$ F41471: Confidential No.B15, Memorandum to the Central Board, Balance of Payments and Foreign Exchange Reserves Position and Prospects, by Division of International Finance, Economic Department, Central Office, RBI, 20/06/1960, p. 123. 
Therefore, they had to pay particular attention to the arguments at the meeting of the Aid-India Consortium in Washington D. C. in April 1961, and favored the friendly and more generous attitudes of donor countries:

While exports have to be stepped up substantially, the reliance of the economy on foreign assistance would continue to be substantial in the next ten to fifteen years. Fortunately for India, world opinion has become favorable but whether foreign assistance in adequate measures and in a flexible enough form will be forthcoming, will be clearer after the projected meeting of India's creditor countries in the last week of April. ${ }^{29}$

As a prerequisite for the Third Five-Year Plan, the Executive Director of the RBI, B. K. Madan, emphasized regional economic cooperation or a new framework of regional trading order in Africa and Southeast Asia, in order to achieve an increase in Indian exports and to obtain more foreign exchange:

Further, there is need to formulate a consistent and well-integrated foreign economic policy towards the underdeveloped countries in Africa and South East Asia. It has to be realized that it is these countries which would provide the markets for India products in future ... The talk of regional grouping in South East Asia is very much in the air at present ... It is obvious that formation of such a group would have a great bearing on India's foreign trade and India should participate in any such scheme and derive such advantage as economic cooperation in the region offers. India being more advanced in this region than any many Asian countries except Japan, can meet some of the capital goods as well as more and more of the consumer goods requirements of these countries in the way of light engineering goods ... While the promotion of exports remains the long-term strategy, the gap can be filled in the short-term only through adequate foreign assistance. ${ }^{30}$

As a longer-term strategy for improving the balance of payments in

${ }^{29}$ F41476: Appendix 1, India's Balance of Payments at the Start of the Third Plan, by Division of International Finance, Economic Department, RBI, 22/04/1961, pp. 513-14.

${ }^{30}$ F41481: II The Balance of Payments----April-September 1961 Preliminary Actuals), by B.K. Madan, Executive Director, RBI, Central Office, 16/02/1962, pp. 228-31 . 
India, the formation of regional economic cooperation in South East Asia and Africa (Indian Ocean Rim areas), in which India kept a leading position as an industrialized country, was indispensable for the Indian authorities. As the steady progress of 'import-substitution' industrialization in India through the Second and Third Five-Year Plans, the prospects for increased exports of manufactured goods became an urgent need for India.

\subsection{B. K. Nehru's Propaganda for Economic Aid in the USA}

After his appointment as Commissioner-General for Economic Affairs of India, Washington D. C. in August 1958, B. K. Nehru occasionally made public speeches in the US about the Indian economic challenge. His main aim was to attract more sympathy and financial support from the US government and the business community.

In May 1960, he delivered the following speech, entitled "The Economic Challenge in India: Can Democracy meet it" at the Economic Club of Detroit, Michigan:

India has become a symbol of development through democracy just as China is a symbol of development through totalitarianism. And though we do not claim to be engaged in any economic race with any part of the world, it is patent that a large number of countries are watching with considerable interest developments in these two giants of Asia in order to see which one has better solution to their problems.

... The challenge to Indian democracy is in these conditions only one and that is economic ... We had to strike out a new path for ourselves, a path that would, on one hand, avoid the dangers of totalitarianism and, on the other, the injustices and the wasteful use of resources which often is the result of pure laissez-faire. We started, therefore, on what has come to be known as planned economic development and a mixed economy. ... Democracies, on the other hand, have a sharp limit to the extent to which they can force their citizens to suffer privation. They are compelled to divert to consumption resources which, taking the long view, should go to production. And the result is, therefore, a slowing down in the rate of growth to below that which may be statistically possible. If in these circumstances the rate of growth has to be adequate, the only answer is the importation of foreign capital, whether the capital comes in through private foreign investment or through international agencies or directly 
through foreign governments. ${ }^{31}$

He intentionally tried to appeal to the US business community, by using the logic of the Cold War, or more specifically the economic race with Communist China for development strategy.

He made a similar speech in San Francisco in January $1961 .^{32}$ In addition to these speeches, he contributed an article to The New York Times Magazine, entitled “\$2700 a Year or \$70 a Year” in April 1960. That was the gap between incomes in rich (US) and poor (India) nations. He asserted it could be bridged just as the gulf between rich and poor was bridged in the nineteenth century within nations. In this article, he expressed high expectations of the new Kennedy Administration and the UN resolution of 'The Decade of Development' (1960):

The UN General Assembly at its last session adopted a resolution recommending that there should be a transfer of capital from the developed countries to the under-developed equal to 1 per cent of the national income of the former. It would appear that Kennedy Administration is in sympathy with this proposal, for there are welcome indications that it wishes to urge that burden of financing the external needs of the under-developed world should be shared by the richer countries on some such basis.

... international society should endeavor to achieve the same ends by ending colonialism as soon as practicable and transferring wealth to the poorer nations; that the sacrifices involved in the task are by no means great; but that, whereas in the case of national governments this was done compulsorily, in the case of international society this will have to be done on a voluntary basis, since we do not as yet have a government of the world. ${ }^{33}$

31 "The Economic Challenge in India: Can Democracy Meet It," delivered before the Economic Club of Detroit, Michigan, May 9, 1960, Vital Speeches of the Day, vol. 26, no.22, September 1960, in B. K. Nehru Papers, III-A Speeches/Writings by Him, No.1 [Nehru Memorial Museum \& Library].

"The Under-developed World Today: India's Approach to the Problems Presented," delivered to Commonwealth Club of California, San Francisco, January 13, 1961, Vital Speeches of the Day, vol. 27, no.10, March 1961, in ibid., no.3.

33 “\$2700 a Year or \$70 a Year,” New York Times Magazine, April 16, 1961, in ibid., No. 4. 
He was appointed Indian Ambassador to the USA in July 1961 at the times of the Kennedy administration. When he presented his credentials, he strongly urged the necessity of economic aid to India as follows:

Today we are engaged in the massive task of sustaining and reinforcing democracy by raising surely and steadily the living standards of our people. Your great country under your inspiring leadership has extended generous help to India in her mighty and challenging endeavour. This age of turmoil and conflict is also an era of hope. It is a matter of deep gratification that America with whom we share values and ideals should be our partner in developing the economy of India. ${ }^{34}$

During his term of Ambassador (1961-67), B.K. Nehru could establish an intimate and collaborative relationship with American Presidents, first with J. F. Kennedy, and then after his assassination, with Lyndon Johnson. ${ }^{35}$

\section{THE CHANGing NATURE OF THE AID-INDiA CONSORTIUM FROM THE MID-1960S AND THE INDIAN FOOD CRISIS}

In the middle of the 196os, India was faced with several economic problems: the stagnation of industrial development, the accumulation and financial burden of heavy foreign debts, two successive severe droughts and the food 'crisis' of 1965-67. In addition to these economic and financial difficulties, "there had been a sharp upsurge in defense expenditures, brief wars with China in October 1962 and with Pakistan in 1965, the death of Jawaharlal Nehru in 1964, and the death of his successor as prime minister, Lal Bahadur Shastri, in Jan-

34 "Indian Ambassador to USA Presents Credentials," Ministry of External Affairs, External Publicity Division, New Delhi, 22 September 1961, F.73 (74)—AMS/61 [National Archives of India].

35 B. K. Nehru, Nice Guys Finish Second: Memoirs, Part VII and VIII; Dennis Kux, India and the United States: Estranged Democracies 1941-1991 (Washington DC: National Defense University Press, 1992). Unfortunately, documents and official records of B.K. Nehru as Indian Ambassador are not included in his private papers at Nehru Memorial Museum \& Library. We must compliment this lack of original documents by using US archives. 
uary 1966, a few hours after he had signed the Tashkent accord with Pakistan." ${ }^{36}$ Among these difficult and critical situations, the food 'crisis' of 1965-67 had brought several impacts and changes not only to Indian development policies but also to India's relations with donor countries and institutions. Therefore, the latter part of this article tries to analyze the mutual interaction between India and aid-donors from the mid-196os.

Since the beginning of the Indian Consortium, the World Bank has taken the role of chair of the annual meetings and aid coordination. However, the largest contribution to the Indian Consortium has been made by the US government. Up to the mid-196os, the Indian Consortium usually offered around one billion US dollars annually to India as economic aid, and the share of US capital donation was around 42 per cent, while the World Bank and its affiliate, the International Development Association (IDA: established in 1960) occupied the second position as donor, around 20-25 per cent. In this section, we analyze US aid policies and the World Bank's aid operations toward India, and Indian requests and reactions to them in the 1960 s.

\subsection{US Economic Aid to India in the 1960s and PL 480}

First, we glance at the development of US economic aid to India in the middle of the 1960s, by using US government documents. In 1951 the US began its aid to India as the 'Indo-American Program.' This program was administered by the International Cooperation Administration (ICA) through the Technical Cooperation Mission (TCM) to India, under the authorization of the Mutual Security Act. In 1957 this development assistance was terminated, to be replaced by loans from the newly established Development Loan Fund (DLF) and also

\footnotetext{
${ }^{36}$ Mason and Asher, World Bank, 678.
} 
from the Export-Import Bank of Washington. In November 1961, under the Kennedy Administration, the Agency for International Development (AID) was established to incorporate technical assistance activities and DLF operations, and since then AID programs in India have been administered by the US A.I.D. Mission to India (USAID).

US aid forms have changed with the changing needs of India, as well as changes in the methods of administration of US foreign aid programs. All US aid activities are divisible into five main categories as follows ${ }^{37}$ (in millions of US Dollars):

Table 2. US Aid Activities

\begin{tabular}{lrr}
\hline I. Technical Cooperation & 113.7 \\
\hline II. Malaria Control \& Eradication & 90.2 \\
\hline III. Development Financing & 306.6 & \\
\hline A. Development Assistance to June 1957 & 742.8 & \\
B. DLF Loans & $1,143.0$ & \\
C. AID Loans & 18.3 & \\
D. Orissa Iron Ore Project & 406.4 & \\
E. Export-Import Bank Credits & & $3,352.7$ \\
\hline IV. Food for Peace & 189.7 & \\
\hline A. 1951 Wheat Loans & $2,911.5$ & \\
B. PL 480 Sales Agreements & 15.8 & \\
C. PL 480 Title II & 230.2 & \\
D. PL 480 Title III & 5.5 & \\
E. Miscellaneous Relief Grants & & 5.8 \\
\hline V. Triangular Trade & & $6,179.5$ \\
\hline
\end{tabular}

37 The United States Contribution to Indian Development, by US A. I. D. Mission to India, New Delhi, June 30, 1965, AID (US) INDIA, BOX 555, The US National Archives and Records Administration [NARA II], Maryland, US. 
More than half of all US assistance was designated 'Food for Peace' under the Johnson Administration. ${ }^{38}$ The greatest share of assistance in this field resulted from nine PL 480 sales agreements, the first of which was signed in August 1956. American agricultural commodities, mainly surplus ones, have almost entirely been exported to India under sales agreements executed in accordance with Title I of PL 480. These agreements gave that new phase of US assistance a special significance to Indian economic development.

These agricultural products have constituted an important factor in India's ability to feed and clothe its people and to carry out the economic development programs in its three Five-Year Plans. Their introduction has kept food prices relatively stable and has represented a significant increase in real resources available for development in India. The terms of sale required payment in Indian rupees (local currency) rather than in foreign exchange (US dollars), and most of the rupee sales proceeds are available for the internal financing of India's development programs. This article draws attention to this PL 480 aid to India in the 196os, which suddenly became the focal political/economic point between the US and India on the outbreak of Indian food crisis.

The several PL 480 sales agreements include various provisions as to the use of rupee proceeds. Roughly speaking, under the nine agreements approximately 87.6 per cent is for loans and grants to India to cover the rupee costs of economic development projects, including the Cooley Amendment loans, which might be loaned to Indian subsidiaries or affiliates of American firms and to Indian firms facilitating or enlarging the use of US agricultural commodities, such as private warehouses, mills and transportation. The use of local currency generated by sales of all American agricultural products must

${ }^{38}$ See, D. N. Prasad, Food for Peace: The Story of U.S. Food Assistance to India (Bombay, India: Asia Publisher, 1980); Kristin L. Ahlberg, Transplanting the Great Society: Lyndon Johnson and Food for Peace (Columbia and London: University of Missouri Press, 2008). 
be agreed upon by the Government of India and the US. Therefore, the US A.I.D. Mission participated with various Government of India agencies in planning the use of these sales proceeds.

As for the allocation of all rupee proceeds, over 30 per cent was for projects to control and develop India's water resources for power generation, irrigation and flood control and for the construction of dams and hydro power stations; 18 per cent was for electric power projects; and 11 per cent for assistance to finance institutions for investment in small or medium sized companies. ${ }^{39}$ These facts indicate that most of the PL 480 rupee proceeds were used for the development of infrastructure for India's economic development. By the middle of the 1960s, the PL 480 supplemented DLF/AID Loans to accelerate Indian economic development, or played more important roles than usual development assistance.

4.2 The Indian Food Crisis and the Johnson Administration, $1965-1967$

Before the sudden outbreak of the food crisis in the latter half of 1965 , donor-countries and the World Bank had started to regard Indian agricultural development as questionable for the continuation of Indian economic development. From October 1964 to the end of February 1965, the World Bank sent a special economic mission, headed by Bernard R. Bell, to investigate the Indian economic situation for preparatory consultation with the Indian Government about the forthcoming Fourth Five-Year Plan. This Bell Mission submitted a huge ten-volume report to the Bank. This pointed out three aspects of Indian economic policies which were damaging its creditworthiness and prospects for continued economic growth: namely, high exchange rate policy; administrative controls over imports; and the

${ }^{39}$ U.S. Information Service (Economic Aid Section), "Food for Peace (Public Law 480)," October 1964, National Security Files-Robert Komer, BOX 25, INDIA—Food January-March 1966 [2 of 4] [Johnson Presidential Library]. 
relative neglect of agriculture. ${ }^{40}$

Indian agricultural development in the 1950 s had been slow and Indian food grain production in the early 1960 seached a plateau of around $8 \mathrm{o}$ million tons of grain per year. The economic policy of the Third Five-Year Plan had emphasized the industrial sector, and the development of heavy industry such as iron and steel, machinery and petro-chemicals was the top priority of economic planning. Government indifference or neglect of agriculture and the low prices of agricultural products, especially food grains, conspired to keep agricultural production down and led to huge imports of food grains from foreign countries, in particular from the US, through the framework of PL 480. ${ }^{41}$

In 1960 India signed the largest PL 480 agreement, providing for the shipment of 16 million tons of American grain over the next four years. The PL 480 wheat was a double-edged sword. On the one hand, because it was a very significant part of the grain that entered commercial channels, it permitted the Indian Government to continue its policy of providing cheap food for the urban [poor] masses. In this way it contributed to political stability. On the other hand, it was an important factor in depressing prices to the Indian farmer. In that way it permitted the continued stagnation in food grain production. ${ }^{42}$ In September 1964, India signed a new PL 480 agreement for 4.4 million tons of grain, even though food output increased sharply in the crop year of $1964-65$ as the result of an excellent monsoon season.

However, the food situation in India changed drastically in the

${ }^{40}$ Report to the President of the International Bank for Reconstruction and Development and the International Development Association on India's Economic Development Effort, vol. 1 Main Report (October 1, 1965) [The World Bank Archives].

${ }^{41}$ See B. R. Shenoy, PL480 Aid and India's Food Problem (New Delhi: Affiliated East-West Press, 1974).

42 “India's Food Crisis, 1965-76,” NSC Box 26, Indian Famine Aug.1966-Feb.1967, vol. 5 Appendix: Agriculture \& State Department Histories [Johnson Presidential Library, Austin]. 
summer of 1965. The 1965-66 crop-year of India was scarred by India's most severe, prolonged and widespread drought in living memory of the last 80 years. By the spring of 1966, the drought had resulted in a poor 72 million ton crop and a massive food deficit. To help meet this shortfall, the US shipped 8 million tons of food grains (about $\$ 500$ million) to India during the year. Through rationing, heavy imports from the US, and generous third country donations, India managed to cope with the crisis, averting famine or widespread malnutrition.

By late July 1966, the monsoon rains appeared to have started well. But by October, the outlook had changed. Seventy-five million people in the Bihar, Uttar Pradesh and Madhya Pradesh heartland faced barren fields, dry wells, unemployment and famine. With the estimates placing the $1966-67$ crop at 78 million tons, only slightly higher than 1965-66, and drought and food scarcity looming in north central India, a food emergency faces the nation for the second successive year. $^{43}$

At the critical stage of the second-year food crisis (1966), in the autumn of 1966, B. K. Nehru strongly requested US officials for an immediate supply of food by using the PL 480 framework. On November 16, Undersecretary of Department of State, Eugene V. Rostow, called Ambassador Nehru into the Department to discuss the Indian food crisis. The discussion centered on India's immediate need for food grains to avert famine in Bihar and other areas of north central India. Nehru expressed his apprehension about the current grave Indian political/economic situation and his disappointment and concern over US delay in releasing the pending two million to food grain allocation for India.

Concerning Nehru's statement, Eugene Rostow suggested that

${ }^{43}$ Information Memorandum: from NEA-William J. Handley to Mr. W. Howard Wriggins, National Security Council, Executive Office of the President, "The Indian Food Crisis: I. 1965-66; II. 1966-67 The US Role-The International Response-The Indian Effort," December 17, 1966, E-Economic Affairs (Gen) E8 Food Situation July-September, RG 59 Lot 69D29 Entry 5254, Records Relating to Indian Economic Affairs, 1964-1966, BOX11 [NARA II]. 
India should tide itself over this difficult period with commercial wheat purchases. In a strong response, Nehru stated that India simply didn't have sufficient foreign exchange to sustain commercial food purchases. It had to be made with free foreign exchange, but this category of foreign exchange also had to be used for debt servicing, and imports of military hardware. Were India obliged to resort to commercial wheat purchases, the Indian economy would break down in the face of shortages and the Government of India would have to stop paying its debts. He strongly insisted that India "can't both buy food and pay debts" and requested the immediate reconsideration of the unwise US approach to the PL 480 program. Rostow finally agreed to explore other financial arrangements rather than commercial purchases to assure the continuity of the food supply pipeline to India. ${ }^{44}$

This episode reveals the tough and skillful negotiations of Indian representatives, especially B. K. Nehru, in the deepening process of the food crisis and his strong determination to solve the crisis. He could utilize, and took advantage of, his intimate personal connection with President Johnson and the intellectual network of pro-American factions.

5. THE 'FOOD CONSORTIUM' AND THE WORLD BANK: THE INTERNATIONALIZATION OF THE FOOD CRISIS

On February 6, 1967, in his message to Congress on Indian Food, Johnson indicated that the US would consider allocating an additional three million tons of food grains, valued at $\$ 190$ million, for delivery to India during 1967 , if this contribution were matched by other countries. These matching contributions could be in the form of

${ }^{44}$ Memorandum for Conversation, (no title), November 16, 1966, E-Economic Affairs (Gen) E8 Food Situation, July-September, BOX 11 [NARA 2]. 
food, fertilizer or cash with which India could purchase foodstuffs or pay for freight.

The World Bank undertook to coordinate the efforts of countries to share in providing food aid to India. This was done within the framework of the Consortium, but the Consortium involvement with providing food aid to India was of a purely emergency nature. The US Johnson Administration also tried to 'internationalize' the Indian food crisis in order to avoid political criticism within the US Congress of an increase in food aid to India. For the American Government, the framework of the Indian Consortium was very useful for indirectly exercising political and financial influence through the multilateral coordinating institution of the World Bank.

For this purpose the Bank proposed to convene a meeting in Paris on April 4, 1967, in order to obtain assurances of aid. At the begging of the 'Food Consortium,' the chairman of the World Bank, I. P. M. Cargill, made the following statement:

The situation this year has been much aggravated by the serious shortages of food caused by the droughts. But food aid is only part of the total aid which India requires in non-project form if import de-control and the associated policy measures are to be sustained and further expanded during the next year ... Action on food is particularly urgent, and I would suggest therefore that members of the Consortium give priority to pledges which will enable the rest of the Consortium to match the US offer of 3 million tons of food. Unless orders for food are placed in the next few weeks, there is no hope of importing the 10 million tons, which now appear to be the bare minimum required for 1967 . . Closely related to this, of course, is the question of debt relief . . . Action to ease the burden of debt." 45

As this remark indicated, food aid was closely related to other big problems which India faced in the late 196os, that is, the increase in non-project aid and debt relief. The premise behind that was that food aid and non-project aid are complementary, because if there was a shortfall in aid available to meet India's food import require-

45 India Consortium: Statement by Chairman on April 4, 1967, INDIA Consortium Meetings - 1967, Vol. 3 [World Bank Archives]. 
ments, export earnings would be diverted from other uses to purchase food grains and thus widen the foreign exchange gap required to be covered by non-project aid.

As for 1967, new food aid from non-consortium member countries was not expected to exceed \$25 million, which left a gap of \$170 million. Within the consortium, Canada considered an additional offer of \$45 million, leaving a gap of around \$120 million in food aid from consortium members other than the US and Canada.

The World Bank made a proposal of $\$ 120$ million in food aid for India to 8 other countries, on the assumption that the aid would be shared among the eight countries in the same proportions as 1965/66 pledges of general development aid. Consortium members were asked to bear in mind that food aid and non-project aid are complementary. If 1967 non-project aid were estimated as \$900 million, it would rise to $\$ 1000$ million (or more, because of disbursement lags and similar difficulties) if there were to be a shortfall of $\$ 100$ million in the provision of food aid. ${ }^{46}$ Finally as food aid requirements, Consortium members agreed to provide food grain on a matching basis, due to strong US pressures for burden sharing of food aid. Some Consortium members rushed wheat and flour and other types of food to India to meet the Indian food shortage. Others who could not provide food aid increased their non-project aid to enable the Indian Government to import food.

As for the total non-project aid requirements, it was agreed that the total amount of non-project aid including food aid and "cash" relief for India during the fiscal year 1967/68 should be about $\$ 1.3$ billion. Part of this amount should be quickly disbursed aid in order to allow India to effect the necessary food purchases without reducing other necessary imports and to ease her foreign exchange position in

${ }^{46}$ India Consortium-1967 Food Aid Requirements, February 16, 1967 IND 67-3, By the World Bank, in INDIA-Consortium-FOOD AID (A1845052) [World Bank Archives]. 
1967. The total pledge of non-project aid was $\$ 610$ million, less than half of India's required amount. Consortium members agreed to convene a Consortium meeting again in the autumn of 1967 in order to review progress towards the targets for $1967 / 68$ non-project aid. ${ }^{47}$

The agreement of PL 48o was finally signed on June 24, 1967, as the first rains of the new monsoon were falling, a monsoon which proved to be the best in recent years. Thus the Indian food crisis ended, as the summer monsoon of 1967 brought forth the largest crop in India's history. A US official document recorded and self-applauded the so-called rescue operations of the Johnson Administration to India in 1965-67 as follows: "India received over 8 million tons of PL 480 grain in 1965-66 and over 6 million tons in $1966-67$. . . It was the largest shipment of food ever made from one country to another." ${ }^{8}$

\section{CONCLUSION}

In this article, we have observed the development of the Aid-India Consortium from the late 1950 os to the late 1960 s. We may point out the following three things as the features of international order of Asia in the 1950s and 196os.

First, the Aid-India Consortium formed a proto-pattern for the Official Development Assistance (ODA) programme in the late 1950s, through bilateral aid as well as multi-lateral aid coordination. In the delicate negotiations with donor countries and international institutions, like the IBRD (The World Bank) and the IMF, the government of India and the Reserve Bank of India (RBI) skillfully played very crucial roles in the development of 'economic diplomacy', taking advantage of, or utilizing, the balance of the Cold-War regime for their

${ }^{47}$ Letter from European Office to I.M.P. Cargill, "Meeting of the India Consortium," April 14, 1967, INDIA Consortium Meetings - 1967, vol. 3 [World Bank Archives].

48 “India's Food Crisis, 1965-76," NSC Box 26, Indian Famine Aug.1966-Feb.1967, vol. 5 Appendix: Agriculture \& State Department Histories [Johnson Presidential Library]. 
own economic and financial benefit. Especially, several veteran civil servants, such as B.K. Nehru and the Finance minister, Morarji Desai, took a strong initiative for the smooth operation of the Aid-India Consortium, with the strong support of Prime Minister Jawaharlal Nehru. The Nehru Administration could manipulate the balance of power of the donor countries and institutions, including the USSR, for the acceleration of Indian economic development.

Second, we may observe the changing nature of the Aid-India Consortium itself in the 196os. The arguments at the Aid-India meetings in 1963-64 tended to emphasize the importance of non-project aid and general purpose aid assistance, especially on the British side (The Treasury and the Bank of England). This change of tone reflected the accumulation of Indian debts through the Third Five-Year Plan. At the end of the Third Plan, the Aid-India Consortium changed from economic development assistance to the relief of a debtor nation, especially after the devaluation of the Indian rupee in 1966. However, as a regional industrialized power in South and Southeast Asia, India tried to explore the possibility of regional economic cooperation in these regions to create a new international economic order. The promotion of Indian exports, including manufactured goods, was closely connected with economic aid.

Third, the presence of the multilateral framework for aid to India, the Aid-India Consortium led by the World Bank, was crucial to the acceleration of the economic development of India, especially for overcoming its food crisis. The World Bank took the lead in holding the 'Food Consortium' in April 1967 and strongly persuaded Consortium members as well as non-member countries to cooperate in food aid to India. In April 1967, just after the 'Food Consortium' in Paris, the Indian Deputy Prime Minister, Morarji Desai, made a speech in gratitude for the food aid from Consortium countries and the World Bank: "a forum like the Consortium represents a significant devel- 
opment in international cooperation. It cannot function effectively or profitably without the utmost goodwill and understanding among all its members, whether they are recipients or donors. If the Aid-India Consortium, which was the first Consortium of its kind, has been able to sustain, despite ups and downs, a constructive interest in Indian economic development among so many countries around the world for nearly nine years now, the credit for it goes largely to the World Bank authorities." ${ }^{49}$ The Bank's Report in 1968 also evaluated the Consortium's record as follows: "The Consortium can probe deeper and recommend stronger changes in Indian development policies and programs than an individual donor country, since its international character eliminates problems of national sensitivities and sovereignty. ${ }^{\circ}$ The World Bank Group itself had its own financial problems, especially a shortage of IDA development funds and delay in their replenishment. We have to reconsider the limitations and achievements of the India Consortium further from global and regional perspectives.

49 Statements by Deputy Prime Minster Desai in the Lok Sabha on April 8, INDIA-Consortium Meetings-1967, vol. 3 [World Bank Archives].

50 Working Paper: India Consortium (80480) (World Bank, July 1968) p. 39; http:documents.worldbank.org/curated/en/1968/07/18129542.consortium. 